DOI: $10.31866 / 2410-1915.21 .2020 .208268$

UDC 7.097:347.78

\title{
LEGAL REGULATION OF TELEVISION PROGRAMME FORMAT AS A MEDIA PRODUCT
}

\author{
Anastasiia Zaitseva
}

PhD in Cultural Studies, ORCID:0000-0002-4792-824X, a.zayc81@gmail.com, Kyiv National University of Culture and Arts, 36, Ye. Konovaltsia St., Kyiv, 01133, Ukraine

\section{For citations:}

Zaitseva, A. (2020). Legal Regulation Of Television Programme Format as a Media Product. Culture and Arts in the Modern World, 21, 281-290. https://doi.org/10.31866/2410-1915.21.2020.208268.

The purpose of the article is to analyse the making and development of legal regulation for television format as a unique media product, as well as the means of its copyright protection. The article uses general scientific and special research methods as the method of theoretical generalisation, the method of analogies and the method of comparative analysis. Referring to the comparative and historical-typological methods, this article is an analysis of the means of legal safeguard, within the framework of intellectual property rights, of television programme format with the corresponding features and functions. The scientific novelty lies in the fact that we have analysed the definitions of the television format concept and studied the state of legal regulation in the world and Ukraine. Conclusions. Thus, in modern foreign and domestic scientific use, there are several definitions for the format of a television programme. Still, this term does not have legislation framework, which negatively affects the legal regulation. However, the legal ambiguity of the definition of "format" gives rise to numerous debates, which can be divided into several categories: the first one sorts out TV format as an idea or a concept, which, according to the legislation of many countries of the world, is not subject to legal protection; to the second one - in the form of a list of specific rules, which are divided into invariable elements of the programme; to the third one - the affinity of the television programme format and literary works; to the fourth one - the conclusions of the Format Recognition and Protection Association (FRAPA), which provided 20 practical pieces of advice how to protect the format. It should be noted that the legal issues of the TV format are assigned to the norms of national legislation, and this is not in every instance effective. At the same time, the modern national legislation provides legal protection for works that are expressed in a physical form and are original and does not extends to any ideas, theories, principles, methods, procedures, processes, systems, methods, concepts, discoveries, even if they are expressed, described, explained, illustrated in work. However, the television programme format cannot be represented only as a copyright object. In our opinion, based on international judicial practice, it is quite logical to provide the television programme with copyright protection and to sign a non-disclosure agreement 
on any information related to the work on the TV format. This step is an efficient mean and field-proven.

Keywords: format; format of a television programme; format of a TV programme; TV format; copyright object.

\section{Introduction}

The accelerated development of media technologies is based on globalisation, which opens new opportunities and directions and, at the same time, makes new demands. Therefore, the modern formats of media space are changed due to the factors that determine its dynamics, further structuring, increasing the importance of legal regulation in the creation of new types of television products.

Determining what a television programme format is, it is crucial to arrange the framework of categories and concepts, which allows predicting clearly not only the expected economic attractiveness of the mentioned product but also all the means of its legal protection, taking into account its features.

Thus, the relevance of the chosen topic is determined by the necessity to study the state of legal regulation of the television programme format and the means of its copyright protection.

\section{Purpose of the article}

The purpose of the article is to analyse the making and development of legal regulation for television programme format as a unique media product, as well as the means of its copyright protection.

The article uses general scientific and special research methods: the method of theoretical generalisation, the method of analogies and the method of comparative analysis. Referring to the comparative and historical-typological methods, this article is an analysis of the means of legal safeguard, within the framework of intellectual property rights, of television programme format with the corresponding features and functions.

\section{Main research material}

The study of the state of legal regulation and the means of its copyright protection is impossible without defining the concept of the television programme format. Moreover, the ambiguity in the definition of television formats requires an analysis of the essential characteristics of this concept, which will allow separating it from other similar ideas.

Today, there are many definitions of what a television format is. A. V. Chuzhykov (2013) defines the format as a television product that has its identification uniqueness (p. 218). The researcher represents the format from the standpoint of its commercialisation component and notes that it is a creative, information and psychological model of consumption adapted for a specific country. The success of the format depends on taking into account the audience prefer- 
ences and the possibility of further exploitation of the artistic images created on the screen. The experts from the Institute of Interactive Television (ITV Institute) believe that the format is a particular structure of the programme, the style that dominates in it (Gurian, 2002). I. M. Kemarskaia's definition is more detailed, who refers to the format as a system of agreements with a viewer of each specific programme, that what makes it unique, not like others and similar to itself (Kemarskaia, 2009, p. 40).

These characteristics, of course, emphasise the main features of the television format, but at the same time, are incomplete. The experts of TV Formats company were the closest to the understanding of the mentioned TV product, who noted that there are no strict, fixed rules for determining the TV format ("Format creation", n.d.). The experts consider that to get closer to the understanding of the format of this or that programme, and it is necessary to provide a detailed description, which may contain some elements: the title, target audience, predictable place in the broadcast network, timing, brief description, operating procedure, budget, design features, commercial components and more.

The word "format" (from the Latin formo - to give form) was used in the printing industry since about the 18th century and referred to the size of the printed edition or sheet. The Oxford Dictionary of English Etymology gives a similar meaning: "generally accepted, established structure of the book, which is characterised primarily by the size of the printed sheet" (Onions, 2004, p. 371). It should be noted that concerning printed products, the format is a concept that reflects the standards of the printing industry.

Since the early 1950s, the concept "format" has entered into the radio sphere, where it was used to define a set of musical directions at first. Since the 1970s it has been used to determine the principles of radio station programming.

With the emergence of television, the concept of "format" has become widely used in this sphere. Initially, it was used to indicate only the quantitative characteristics of the television process, more precisely - the programme timing. Already at the beginning of the $21^{\text {st }}$ century, owing to the active development of the process of differentiation and specialisation of broadcasting, the concept of "format" is enriched with new meanings relating not only to merely external technical parameters, but also conceptual, informative properties. David Altheide gave this extended conceptual interpretation in his work Media Logic in 1979. The researcher defines the format as a specific framework or perspective that is used to represent or interpret certain phenomena. He also notes that the format is primary concerning the event, as it is namely the event that is constructed according to the format, not vice verse (Altheide \& Snow, 1979, p. 75).

One of the first researchers of the format, Albert Moran, stressed that the very question of a clear definition of the scope of this concept is not a good idea since the format is a free term that covers a wide range of issues that can be included in the license agreement. The concept of this notion should be revealed not through the question "what is it?", but through the understanding of what it allows or facilitates; it is an economic and cultural technology of exchange, the sense of which is not in the principles, but in the technology or the effect that is created (Moran, 2004, p. 6). 
From the above mentioned, it becomes clear that the formats are one of the most complex objects in the media market. The rights to use them are sold and bought for a large amount of money. At the same time, "format law" has not been created yet. Such international legal documents as the Berne Convention for the Protection of Literary and Artistic Works and the Universal Copyright Convention (Geneva Act), do not establish the concept of television format or another similar one. Accordingly, the issue of legal regulation of the TV format is entrusted to the rules of national legislation. In 2004, on the basis of the court decision in the case concerning the TV programme "Big brother" (Brazil), it was stated that the TV format is a much broader concept that covers not only the central idea of the programme but also a large group of technical, artistic, economic and business information (Fedorova, 2014, p. 30).

The legal ambiguity of the definition of "format" gives rise to numerous debates, since many researchers consider that the TV format is an idea or a concept that, according to the legislation of many countries of the world, is not subject to legal protection. According to Paragraph 3 of Art. 8 of the Law of Ukraine "On Copyright and Related Rights" the legal protection extends only to the form of expression of work. It does not apply to any ideas, theories, principles, methods, procedures, processes, systems, means, concepts or discoveries, even if they are expressed, described, explained or illustrated in work (Verkhovna Rada Ukrainy, 1993).

Some researchers try to present the conception of the programme in the form of a list of specific rules. The authors of this approach distinguish fixed (invariable) and variable elements of the programme (Oren \& Shahaf, 2012, p. 16). Albert Moran said a few words about it. He considers that the TV format is a set of invariable elements of the programme, outside of which the variable elements of the individual episode are produced (Moran, 2004, p. 7). Thus, this principle of division of format elements is an interesting suggestion. But, at the same time, it is worth agreeing with A Shtefan (2016), who considers that this approach reveals the essence of the subject under study only partially (p. 50). The researcher notes that the basis of the TV format is not the concept itself, but the finished product in the form of a television programme. A. Shtefan (2016) notes that the TV format is an explicit instruction that reveals the technology of television programme production, and not just its idea (p. 51). Of course, an idea or a concept can be considered as its integral elements, but its essence is not reduced to them. It should be noted that the researcher suggests not to limit the protection of the format only employing copyright. The TV format includes, in addition to the script, such components as phonograms, trademarks, various objects of patent rights (industrial designs), information of a financial, production, organisational and other nature, which is a trade secret. Taking that into consideration, the Ukrainian legislation provides a wide range of opportunities for the legal protection of all significant components of the TV format (Shtefan, 2016, p. 57).

Many researchers attribute the format of a television programme to literary works. Therefore, at first sight, it is quite logical to provide it with legal protection as a copyright object. But, at the same time, it should be noted that 
this is not an ordinary kind of literary art. As Robin Meadow notices, the format differs from a literary work in its purpose, since it cannot be performed (like a play, for example) or read as an ordinary literary work. The primary use of the format, in researchers' opinion, is to ensure the integration of invariable and variable elements and the formation of an exciting programme on this basis, close to forming addiction in them. The researcher proposes criteria with the help of which you can determine the protectability of the television programme format: novelty and completeness of the work (Meadow, 1970, p. 1192). Robin Meadow (1970) emphasised the similarity of formats and literary works, which is a strong argument for the legal protection of TV programme formats as copyright objects (p. 1171).

N. Fedorova (2014) distinguishes the following elements of the TV format: first, a unique combination of elements that together form an integral programme; secondly, a specific general idea, which is expressed in a physical form; thirdly, the TV programme format is a particular template for reproduction both in different episodes of a particular series of programmes and in various realisations of the format (in other programmes); fourthly, it is intended for multiple achievements in various ways (p. 31). This list is complete and allows determining the main directions of providing legal protection of the TV programme format. The modern national legislation provides legal protection for works that are expressed in a physical form and are original (O. A. Pidopryhora \& O. O. Pidopryhora, 1998, p.6). But at the same time, the immediate subject of protection is namely the form of the work, not its content, which also raises many questions that return to the idea or concept of TV format again. The ways for solving this problem are suggested by experts from the Format Recognition and Protection Association (FRAPA). The organisation website provides 20 practical pieces of advice on how to protect the format ("Practical advice to protect", n.d.). The experts suggest documenting each stage of work on the format in detail. First of all, its detailed description should be written down. Today there is a similar practice, which consists of the use of the so-called "format bible" or "format bible generator". This document details information on the title, its script, logo, description of the studio settings, costumes, style of behaviour of presenters and other characteristics of the programme. But, taking into consideration the peculiarities of national legal systems, this step is not always effective. As an example, the case under claim by the Spanish company Gestmusic Endemol against Channel One (Russia), which appealed to the Moscow City Arbitration Court (case No. A40-84902 / 2014), should be considered (Grigorev, 2015). It demanded to stop broadcasting the programme "Exactly the same" ("Toch-v-toch") for it copied the original format of the show "Your face sounds familiar" entirely, the exclusive rights to which belong to the claimant, and thus violates them.

Substantiating its claims, the claimant referred to the so-called "production bible" of the programme format, which contains the description of the original Spanish TV show. Channel One insisted in court that the "Exactly the same" programme was a project of their production, the script for which was written by actor Oleksandr Oleshko. At the same time, the representatives of the channel did not deny the similarity of the concepts of TV programmes. Still, 
they noted that Russian legislation does not provide for such copyright object as the format (Grigorev, 2015).

The court dismissed the complaint, resolving that the format "production bible" is only a description of the conception of the Spanish television programme, which already exists, as well as the principles and methods of its creation, which cannot be considered protected under paragraph 5 of Article 1259 CC RF, since they are not part of its form, but represent elements of its content. Such means, methods, ideas and sequences of actions do not belong to the creative process, but only describe the technology of production. Therefore, they cannot be considered the copyright object. Taking into consideration those mentioned above, it is worth agreeing with the position of both national and foreign experts, who emphasise that one of the most effective means in the fight against format copying is the care of television companies for their reputation, which has a direct impact on their position in the global media market (Shtefan, 2016, p. 58).

FRAPA's experts also advise registering marks for goods and services that will allow fixing the title, its design, certain design elements or other important visual components of the created format. It is clear that in the process of creating any new product, the measures for its confidentiality should be taken. That is why an agreement on non-disclosure of any information related to the work on the TV format should be signed. There are also recommendations for the signing of the non-disclosure agreements with a potential buyer of TV products. This step is an efficient mean and field-proven.

\section{Conclusions}

Thus, in modern foreign and domestic scientific use, there are several definitions for the format of a television programme. Still, this term does not have legislation framework, which negatively affects the legal regulation.

The legal ambiguity of the definition of "format" gives rise to numerous debates, which can be divided into several categories: the first one includes TV format as an idea or a concept, which, according to the legislation of many countries of the world, is not subject to legal protection; to the second one - in the form of a list of specific rules, which are divided into invariable (content, visual, musical, technical, which together reflect the general idea) and variable programme elements, formed based on constants, make a unique combination; to the third one - the affinity of the of television programme format and literary works; to the fourth one - the conclusions of the Format Recognition and Protection Association (FRAPA), which provided 20 practical pieces of advice on how to protect the format: the title, its script, logo, description of the studio settings, costumes, style of behaviour of presenters and other characteristics of the programme. FRAPA's experts also advise registering marks for goods and services that will allow fixing the title, its design, certain design elements or other important visual components of the created format.

However, taking into consideration the peculiarities of national legal systems, since the issue of legal regulation of the TV format is entrusted to the rules of national legislation, this step is not always effective. 
The modern national legislation provides legal protection for works that are expressed in a physical form and are original and does not extends to any ideas, theories, principles, methods, procedures, processes, systems, methods, concepts, discoveries, even if they are expressed, described, explained, illustrated in a work. However, the television programme format cannot be represented only as a copyright object, since it contains elements that are subject to legal protection as an object of related rights, know-how, trade secrets, some objects of design rights. Also, on the basis of international judicial practice, it is necessary to attribute this concept to the intellectual property rights, which is a complex object, significant components of which have the means of legal protection by the rules of Ukrainian law.

In our opinion, it is quite logical to provide the television programme format with copyright protection and to sign an agreement on non-disclosure of any information related to the work on the TV format.

\section{References}

Altheide, D., \& Snow, P. (1979). Media Logic. Sage Publications [in English].

Chuzhykov, A. V. (2013). Ekonomichni peredumovy komertsializatsii yevropeiskykh teleproduktiv v Ukraini [Economic prerequisites for the commercialisation of European TV products in Ukraine]. Visnyk Lvivskoi komertsiinoi akademii. Seriia ekonomichna, 42, 217-226 [in Ukrainian].

Fedorova, N. (2014). Teleformat yak obiekt pravovoi okhorony [Teleformat as copyright object]. Theory and practice of intellectual property, 4, 29-34 [in Ukrainian].

Format creation. (n.d.). TV formats. http://www.tvformats.com/formats.html [in English].

Grigorev, D. (2015, January 20). "Format" kak obekt avtorskogo prava ["Format" as copyright object]. Zakon.ru. https://zakon.ru/blog/2015/1/20/format_kak_obekt_ avtorskogo_prava [in Russian].

Gurian, P. (2002). TV show format. In The interactive television dictionary. Grand Natl Pr [in English].

Kemarskaia, I. N. (2009). Format i telestcenarii [Format and television script].Zhurnalist, 6, 40 [in Russian].

Meadow, R. (1970). Television Formats - The Search for Protection. California Law Review, 58, 5, 1169-1197 [in English].

Moran, A. (2004). Television formats in the world / the world of television formats. In A. Moran, \& M. Keane (Eds.), Television across Asia. Television Industries, Programme Formats and Globalization (pp. 1-8). Routledge Curzon [in English].

Onions, C. T. (Ed.). (2004). The Oxford Dictionary of English Etymology. Clarendon Press [in English].

Oren, T., \& Shahaf, S. (2012). Television Formats - A Global Framework for TV Studies. In T. Oren, \& S. Shahaf (Eds.), Global Television Formats: Understanding Television Across Borders (pp. 1-20). Routledge [in English].

Pidopryhora, O. A., \& Pidopryhora, O. O. (1998). Pravo intelektualnoi vlasnosti Ukrainy [Intellectual property law of Ukraine]. Yurinkom Inter [in Ukrainian].

Practical advice to protect your format. (n.d.). Frapa.org. https://www.frapa.org/formatregistry/ [in English]. 
Shtefan, A. S. (2016). Format teleperedachi: sutnist, zmist, pravova okhorona [Broadcast format: nature, content, legal protection]. Theory and practice of intellectual property, 1, 49-58 [in Ukrainian].

Verkhovna Rada Ukrainy. (1993). Pro avtorske pravo ta sumizhni prava [On Copyright and Related Rights]. Law of Ukraine of December 23, 1993 № 3792-XII. http://zakon. rada.gov.ua/cgi-bin/laws/main.cgi?nreg=3792-12 [in Ukrainian].

\section{ПРАВОВЕ РЕГУЛЮВАННЯ ФОРМАТУ ТЕЛЕВІЗІЙНОЇ ПЕРЕДАЧІ ЯК МЕДІАПРОДУКТУ}

\section{Зайцева Анастасія Вікторівна}

Кандидат культурології, ORCID:0000-0002-4792-824X, a.zayc81@gmail.com, Київський національний університет культури і мистецзтв, Київ, Україна

Мета статті - проаналізувати процес становлення та розвитку правового регулювання формату телевізійної передачі як особливого медіапродукту, а також можливості його правової охорони нормами права інтелектуальної власності. У статті було використано загальнонаукові та спеціальні методи дослідження, зокрема: метод теоретичного узагальнення, метод аналогій та метод компаративного аналізу. Звертаючись до порівняльного та історико-типологічного методів, зазначена стаття являє собою аналіз можливостей правової охорони, в межах права інтелектуальної власності, формату телевізійної передачі 3 відповідними властивостями та функціями. Наукова новизна полягає в тому, що проаналізовано визначення поняття «телевізійний формат» і досліджено його стан правового регулювання в світі та Україні. Висновки. Отже, в сучасній зарубіжній та вітчизняній науковій думці існує кілька визначень формату телевізійної передачі, але законодавчого закріплення зазначене поняття не має, що негативно позначається на правовому регулюванні. Однак правова невизначеність дефініції «формат» породжує численні дискусії, які можемо поділити на кілька категорій: до першої віднесемо телеформат як ідею або концепцію, що, згідно із законодавством багатьох країн світу, не підлягає правовій охороні; до другої - у вигляді списку певних правил, що поділяються на незмінні та змінні елементи програми; до третьої - спорідненість формату телевізійної передачі та літературних творів; до четвертої - висновки FRAPA, яка надала 20 порад, що дозволять захистити формат. Наголосимо, що питання правового регулювання телеформату покладено на норми національного законодавства, а зазначений крок не завжди $є$ ефективним. При цьому сучасне вітчизняне законодавство надає правову охорону творам, що виражені в об'єктивній формі та є оригінальними, і не поширюється на будь-які ідеї, теорії, принципи, методи, процедури, процеси, системи, способи, концепції, відкриття, навіть якщо вони виражені, описані, пояснені, проілюстровані у творі. Однак формат телевізійної передачі неможливо представити виключно як об’єкт авторського права. На наш 
погляд, виходячи зі світової судової практики, цілком логічно надавати формату телевізійної передачі правову охорону як об’єкту права інтелектуальної власності та підписувати угоду щодо нерозголошення будь-якої інформації, що пов’язана з роботою над телеформатом. Зазначений крок є дієвим засобом, що перевірений тривалою практикою.

Ключові слова: формат; формат телевізійної передачі; формат телепередачі; телеформат; об’єкт права інтелектуальної власності.

\section{ПРАВОВОЕ РЕГУЛИРОВАНИЕ ФОРМАТА ТЕЛЕВИЗИОННОЙ ПЕРЕДАЧИ КАК МЕДИАПРОДУКТА}

\section{Зайцева Анастасия Викторовна}

Кандидатка культурологии, ORCID: 0000-0002-4792-824X, a.zayc81@gmail.com, Киевский национальный университет культуры и искусств, Киев, Украина

Цель статьи - проанализировать процесс становления и развития правового регулирования формата телевизионной передачи как особого медиапродукта, а также возможности его правовой охраны нормами права интеллектуальной собственности. В статье были использованы общенаучные и специальные методы исследования, в частности: метод теоретического обобщения, метод аналогий и метод сравнительного анализа. Обращаясь к сравнительному и историко-типологическому методам, указанная статья представляет собой анализ возможностей правовой охраны, в пределах права интеллектуальной собственности, формата телевизионной передачи с соответствующими свойствами и функциями. Научная новизна заключается в том, что проанализировано определение понятия телевизионный формат и исследовано состояние его правового регулирования в мире и Украине. Выводы. Итак, в современной зарубежной и отечественной научной мысли существует несколько определений формата телевизионной передачи, но законодательного закрепления указанноепонятие не имеет, что негативно сказывается на правовом регулировании. Однако правовая неопределенность дефиниции «формат» порождает многочисленные дискуссии, которые можем разделить на несколько категорий: к первой отнесем телеформат как идею или концепцию, которая, согласно законодательству многих стран мира, не подлежит правовой охране; ко второй - в виде списка определенных правил, которые делятся на постоянные и переменные элементы программы; к третьей - родство формата телевизионной передачи и литературных произведений; к четвертой - выводы FRAPA, которая предоставила 20 советов, позволяющих защитить формат.

Отметим, что вопрос правового регулирования телеформата возложен на нормы национального законодательства, а этот шаг не всегда является эффективным. При этом современное отечественное законодательство предоставляет правовую охрану произведениям, выраженным в объективной форме и являются оригинальными, и не распространяется на идеи, теории, принципы, методы, процедуры, процессы, системы, способы, концепции, открытия, даже если они выражены, описаны, объяснены, 
проиллюстрированы в произведении. Однако формат телевизионной передачи невозможно представить исключительно как объект авторского права.

На наш взгляд, исходя из мировой судебной практики, вполне логично предоставлять формату телевизионной передачи правовую охрану как объекту права интеллектуальной собственности и подписывать соглашение о неразглашении любой информации, связанной с работой над телеформатом. Этот шаг является действенным средством, проверенным длительной практикой.

Ключевые слова: формат; формат телевизионной передачи; формат телепередачи; телеформат; объект права интеллектуальной собственности. 